\title{
The contribution of rainfed rice farming to income and food security of farmers' household
}

\author{
Arifin $^{1 *}$, Muhammad Arsyad Biba ${ }^{2}$ and Syafiuddin ${ }^{3}$ \\ ${ }^{1}$ Muslim University of Maros, Indonesia \\ 2Pioneer Institute of Agriculture and Living Environment, Indonesia \\ ${ }^{3}$ Muhammadiyah University of Makassar, Indonesia \\ *Correspondence email: arifin.maros13@gmail.com
}

\section{ARTICLE INFO}

\section{- Research Article}

\section{Article History}

Received 23 February 2021

Accepted 28 May 2021

Published 1 October 2021

\section{Keywords}

food expenditure; food security; rainfed; rice farming;

\section{JEL Classification} Q12; Q18; R14

\begin{abstract}
Increasing production from rainfed rice field farming is expected to have direct implications to farmers' income and food security. Improvement in farmers' income will ensure the fullfillment of quality food. This study aims to analyze the contribution of rainfed rice farming to the household income and household food security of the farmers who cultivate rice in rainfed rice fields. This research was conducted in Maros Regency in three districts, namely Lau, Maros Baru and Simbang. The sample of this research was 100 farmers in rainfed rice fields. The research used survey method with the instruments of observation, recording and interviews. Data were analyzed using quantitative description coupled with t-test for independent samples. The results showed that the rainfed rice farming contribution to the household income in Lau, Maros Baru and Simbang District was $90.0 \%, 70.0 \%$, and $57.5 \%$, respectively. In term of farm household food security based on the share of food expenditure, the farmers' households were food insecure with $73.33 \%, 83.33 \%$, and $67.50 \%$ for each regions. This study suggests that farmers need to diversify their income source to crops other than rice. Such effort will be able to increase the income and food security of farmers' households.
\end{abstract}

To cite this article: Arifin, Biba, M. A., \& Syafiuddin. (2021). The contribution of rainfed rice farming to income and food security of farmers' household. Journal of Socioeconomics and Development, 4(2), 180-188. https://doi.org/10.31328/jsed.v4i2.2252

\section{INTRODUCTION}

The main activities and the major source of income of most people in rural areas still depend on the agricultural sector. It can be indicated that the livelihoods of most households depend on the agricultural sector (Anton \& Marhawati, 2016). The agricultural sector accommodates more than $30 \%$ of the workforce, which in this case are farmers. Farmers are the first people who play a role in providing food for the community (Prasetyaningtyas \& Nindya, 2017). Most of them are small farmers who have low income and are classified as poor (Aminah et al., 2015). More than $50 \%$ of the poor people in rural areas work in the agricultural sector (Feryanto, 2017). Rice commodity has a strategic priority in agricultural development, serving as the main food of most Indonesians, both in rural and urban areas (Setiawati et al., 2016).

Agriculture is the driving force for other sectors as it supports the goals of agricultural development, farmer's living standard, expand employment, and business opportunities in encouraging economic development. The growth dynamics of the rural economy will provide more opportunities for the 
people's welfare especially in the countryside (Anton \& Marhawati, 2016). Efforts to increase income and maintain the existence of lowland rice farming must be a priority for agricultural development. Rice farming is still a strategic program for agricultural development because, in addition to meeting the basic population food needs, rice farming absorbs labor and provides an income source for rural residents (Bulanta et al., 2019).

The national demand for rice continues to increase from year to year due to the increase in population. Thus, it is necessary to increase and develop other potential rice fields including rainfed rice. Rainfed rice is the second national rice producer after wetland rice. The development of rainfed rice is still facing problems, with the low productivity standing out (René et al., 2016). Rice production in rainfed farms cannot be separated from the problem of water availability which only relies on rainwater (Nurdin, 2010).

Rainfed rice production rate is usually lower than that of wetland rice. The international community in the field of rice research classifies rainfed rice fields as high-risk ecosystems because they are threatened by drought, flooding, salinity, and pest attacks (Arifin et al., 2019). Anticipation of risks is pursued through plant cultivation and cultivation techniques, and management of rice nutrients (Lailiyah et al., 2017). With the conditions and risks in the rainfed rice fields, the income of rainfed rice fields farmers from rice cultivation is limited only at the rainy season (Raes et al., 2007).

Increasing rice production plays an important role in maintaining food security and national economic growth (Siregar \& Yurnaliza, 2017; Razak et al., 2013). Improved production and the role of a good selling price are expected to have direct implications for farmers' income (Tambi, 2019; Tashikalma et al., 2014). Efforts to achieve food security are mostly focused on increasing food self-sufficiency in each region, including provinces, regencies/cities, districts, and villages (Arlius et al., 2017; Pothukuchi, 2004). The increased need for food is in line with the increase in population and community income (Wardie \& Sintha, 2018). These two components determine food needs and further determine food security (Ahmed et al., 2017; Sianipar et al., 2012). Purchasing power is one component of a household's ability to provide food or food affordability (Wardie et al., 2019; Piran et al., 2018).
In general, the motivation of farmers in working on a certain commodity is to get cash through selling the produce in an effort to meet family needs (Sari et al., 2018). The increase in farmers' income will affect the purchasing power of farmers to meet food and other non-food needs (Matus et al., 2012; Purwaningsih et al., 2010). Improvement in farmers' income will ensure the fulfillment of quality food in accordance with the nutritional needs needed (Abdulkadyrova et al., 2016; Arida et al., 2015; Emtamoile et al., 2016). Fulfillment of food reflects the level of welfare of the farmers that will be better (Sianipar et al., 2012).

Food security and poverty alleviation depend in large part on the sustainability of crop production. Rice is the staple food produced and consumed by more than half of the world's population. Rice is also a vital source of billions of people in Asia, as a source of livelihood and support for economic development. For lowland areas in Asia, rainfed and irrigated rice fields account for about $90 \%$ of rice production. Rice production has links to household and national food security, poverty alleviation and political stability in agriculture-based countries (Roy \& Chan, 2015).

Research related to the contribution of rice farming and food security in partially rainfed rice fields, i.e. the contribution of rice farming to rainfed rice separately, as well as household food security of farmers who cultivated rice farming in rainfed rice have been widely carried out. However, research on the contribution of rice farming in rainfed rice fields to farmers' household income by combining it with household food security has never been done, especially in Maros Regency. The purposes of this study are to analyze the contribution of rainfed rice farming to farmers' household income, and to analyze household food security of farmers who cultivated rice in rainfed rice fields.

\section{RESEARCH METHOD}

This research was conducted in three districts of Maros Regency: Lau District (Allepolea Village), Maros Baru District (Mattirotasi Village), and Simbang District (Bonto Tallasa Village). The research location was chosen purposively with the consideration that it is one of the areas that have extensive rainfed rice fields in South Sulawesi. The research period was from March to June 2019.

This study used a quantitative approach coupled with a survey method. The data, comprised of primary 
and secondary data, were collected using observation, recording and interview techniques. The population was farmers who cultivated rice farming in rainfed rice fields at the research location. The population number was 1,035 farmers. The number of respondents was 100 farmers. The samples were selected using the proportional random sampling method in three research locations. Data analysis used a descriptive quantitative technique with independent samples $t$ test.

The analysis of rice farming contributions to farmers household income was formulated as

$$
\mathrm{CRF}=\frac{\text { Farming Income }}{\text { Total Income }} \times 100 \%
$$

Where CRF is the Contribution of Rice Farming. The criteria of rice farming contributions to farmers household income were classified as follows: (a) contribution of rice farming more than $50 \%$ means it contributes to farmers' household income, and (b) contribution of rice farming is less than $50 \%$ means it does not contribute to household income. The criteria for testing used independent samples t-test on the contribution of rice farming to farmers' household income.

Farm household food security can be measured using the share of household food expenditure approach. To find out the share of household food expenditure, the following equation was used:

$\mathrm{SFE}=\frac{\text { Household Food Expenditure }}{\text { Total Expenses }} \times 100 \%$

Where SFE is the share of food expenditure. Indicators of the level of food security were approached with the criteria (i) food share expenditure less than $60 \%$ of total expenditure is food secure households, and (ii) food share expenditure $\geq 60 \%$ of total expenditure is food insecure households. The independent samples t-test was used on household food security of farmers.

\section{RESULT AND DISCUSSION}

\section{Respondent Characteristics}

The characteristics of farmer respondents are a general description of the condition of farmer households who cultivated rice in rainfed rice fields. Characteristics of farmer household respondents examined in this study include farmers' age, farmers' education level, area of arable land, and experience in rice farming. The characteristics of farmer household respondents are presented in Table 1.

Table 1. Respondents' Characteristics

\begin{tabular}{lcc}
\hline Variable & \multicolumn{2}{c}{ Number of respondents } \\
\hline Farmer's age & people & $\%$ \\
$20-40$ years & 43 & 43 \\
$41-60$ years & 53 & 53 \\
$61-80$ years & 4 & 4 \\
$\quad$ Average (years) & 42.6 & \\
Education level & & \\
Elementary school & 41 & 41 \\
Junior high school & 29 & 29 \\
Senior high school & 29 & 29 \\
Bachelor & 1 & 1 \\
Farm size & & \\
$0.10-0.50$ ha & 28 & 28 \\
$0.51-1.00$ ha & 53 & 53 \\
$1.10-1.50$ ha & 13 & 13 \\
$1.51-3.00$ ha & 6 & 6 \\
Average (ha) & 8.9 & \\
Farming experience period & & \\
$\leq 10$ years & 13 & 13 \\
$10-25$ years & 66 & 66 \\
$>25$ years & 21 & 21 \\
Average (years) & 19.9 & \\
\hline
\end{tabular}

Table 1 shows that farmers had an average age of 42.6 years, with a minimum age of 24 years and a maximum age of 72 years. The most dominant age group is $41-60$ years old (53\%), followed by the 20 40 years old group (43\%) and the $61-80$ years old (4\%). Based on this age group, the farmers were dominated by husbands at their productive age as the main actor in the farming activities. Productive age is closely related to physical abilities and the ability to make decisions. In general, as one's age increases, his ability to work will increase to a certain extent, and then decrease afterwards. Farmers in carrying out their activities used agricultural machines (hand tractors) for land preparation. The use of agricultural machinery can speed up work completion and the cost is lighter or affordable to farmers.

The farmers were mostly elementary school graduates, followed by junior and senior high school graduates, and university graduates, respectively. This shows that the level of formal education of farmers is relatively low. The approach to supporting optimal farmer work results is influenced by the level of education. Formal education can determine success for the development of reliable human resources in their fields, and the level of education usually affects 
the way a person thinks. In practice, even though their level of formal education is low, those farmers had been running their farming for a long time. Most of them had been active in cultivating rice since childhood and on average had experience in it. They also attended and received non-formal education from various activities like extension and training programs. With these activities, farmers knowledge will be more advanced to support the progress of their farming.

The arable land managed by farmers was dominated by the area size of $0.51-1.00$ ha, followed by $0.10-0.50$ ha size, $1.10-1.50$ ha, and $1.51-3.00$ ha. This shows that the land area cultivated by farmers varies. Some farmers worked on their own land, but many farmers cultivated other people's land using a production sharing system. The usual production sharing system was that half of the harvest was given to the land owner and the other half was given to the smallholders. The latter had responsibility in processing the fields from land cultivation to harvesting.

Most farmers had the experience of farming for 1025 years, followed by 25 years or over, and less than 10 years. This means that most farmers had been running rice farming for a long time. Most experienced farmers were continuing the business of their parents. Experience is important to support farming activities. Most farmers tended to develop their farming skills from their experience. In general, rice farmers with longer farming experience had better skills and a better understanding of the rice farming process. Farmers' experience was obtained from their parents as an inheritance from generation to generation as well as from non-formal education by agricultural extension agents. Farmers with relatively long farming experience will be able to consider the risks involved in farming.

\section{Rainfed Rice Farming}

Analysis of rainfed rice farming in terms of production, price, revenue, total cost, and average income are presented in Table 2. The analysis of the results of the rainfed lowland rice farming differed on average among locations. In terms of production, revenue, and total costs in the farming analysis component, the production component of Maros Baru District was the highest $(5,246.67 \mathrm{~kg})$, followed by Lau District $(4,820.30 \mathrm{~kg})$ and Simbang District $(4,487.50$ $\mathrm{kg}$ ). The revenue component of Maros Baru District was the highest, followed by Lau and Simbang District.
The total cost component of Maros Baru District was the highest, followed by Lau and Simbang District. The rice price was higher in Lau District compared to Maros Baru and Simbang District, where the rice price in the last two regions was the same. As for revenue, Lau District was the largest, followed by Maros Baru and Simbang District.

Table 2. Rainfed Rice Farming in Selected District, Maros Regency

\begin{tabular}{lrrr}
\hline Item & \multicolumn{1}{c}{ Lau } & Maros Baru & Simbang \\
\hline Production (kg) & 4,820 & 5,247 & 4,488 \\
Price (Rp/kg) & 3,700 & 3,400 & 3,400 \\
Revenue (Rp) & $17,835,110$ & $17,838,667$ & $15,257,500$ \\
Total Cost (Rp) & $3,712,990$ & $3,825,935$ & $3,090,129$ \\
Revenue (Rp) & $14,122,120$ & $14,012,732$ & $12,167,371$ \\
\hline
\end{tabular}

The revenue earned in Lau District was greater than in Maros Baru District, influenced by the rice price and the total cost. The rice production obtained in Maros Baru District was greater but the rice price was lower so that it affected the revenue. The total cost, which was also large, affected the income earned.

\section{The Contribution to Household Income}

The different contributions of rainfed rice farming to farmers' household income in the three locations can be seen using the independent sample t-test analysis (Table 3 ).

Table 3. The Contribution of Rainfed Rice Farming to Household Income in Maros Regency

\begin{tabular}{|c|c|c|}
\hline District & $\mathrm{CRF} \geq 50 \%$ & $\mathrm{CRF}<50 \%$ \\
\hline & \multicolumn{2}{|c|}{$\ldots \ldots \ldots \ldots \ldots$ people $\ldots \ldots \ldots \ldots \ldots \ldots$} \\
\hline Lau & $27(90.0 \%)$ & $3(10.0 \%)$ \\
\hline Maros Baru & $21(70.0 \%)$ & $9(30.0 \%)$ \\
\hline Simbang & $13(57.5 \%)$ & $17(42.5 \%)$ \\
\hline \multicolumn{3}{|c|}{ Rice Farming Contribution t test: } \\
\hline \multicolumn{2}{|c|}{$\mathrm{t}_{\text {count }}$ (contribution by not contributing) } & $10.727 * * *$ \\
\hline \multicolumn{2}{|c|}{$t_{\text {count }}($ Lau with Maros Baru) } & $3.280 * *$ \\
\hline \multicolumn{2}{|c|}{$t_{\text {count }}($ Lau with Simbang) } & $1.403 *$ \\
\hline \multicolumn{2}{|c|}{$t_{\text {count }}$ (Maros Baru with Simbang) } & $2.140 * *$ \\
\hline
\end{tabular}

CRF is Contribution of Rice Farming

$* * *, * *$ and $*$ denote significance at p $0.01,0.05$ and 0.10 , respectively

Table 3 shows that rainfed rice farming accounted for more than $50 \%$ of household income in Lau District, with as many as 27 farmers (90.0\%). In the same way, there were 21 farmers (70\%) and 13 farmers $(57.5 \%)$ in the districts of Maros Baru and Simbang, in which more than $50 \%$ of their income was accounted for by rainfed fields. The t-test results revealed significantly different $(p=0.01)$ calculation, 
indicating that rainfed rice farming contributed to the farmers' household income in three districts.

In comparison, the contribution of rainfed lowland rice farming to the household income of farmers in Lau District was the highest. This was followed by Maros Baru and Simbang District. Meanwhile, the t-test showed significantly different calculation $(p=0.05)$ among districts. Also, Lau and Simbang District displayed significantly different calculation $(p=0.10)$.

Table 3 provides an overview of rainfed rice farming in contributing to household income. Most of the farmers earned their living by cultivating rice in rainfed rice fields as their main occupation. This means that rainfed rice farming is the main source that contributes to household income compared to other businesses. For farmers, rice farming plays a role in providing staple food and a source of household income for farmers (Barokah et al., 2014). The main activities and main source of income for the community, especially people in rural areas, still depend on the agricultural sector. This means that the livelihoods of most households depend on the agricultural sector (Anton \& Marhawati, 2016).

The dependence of farmers on income from farming is still large. This is because farmers have not tried hard to seek additional income apart from farming. This rice farming income is what helps a lot in running the economy and fulfilling the daily needs of farmer families. Therefore, farmers need to diversify in terms of seeking additional income in order to meet family needs. Farmers' motive for diversification is often more oriented towards income stabilization (Nurasa, 2013). Farmers also need to add work skills to find other jobs besides farming.

Farmers' income outside of rice farming is very diverse, both in agriculture and outside agricultural sector (Syamsiyah et al., 2017). Other farms carried out by farmers are typically food crops, maize and pond farming. If the income from farming activities is not sufficient, the farmers' household tries to find work outside of farming and non-agriculture in an effort to meet the needs of family life (Norfahmi et al., 2017). The income of farmers from outside the farm includes rice motorcycle taxi, masons and laborers. With this source of income, the welfare of farmer households can be seen from the fulfillment of the farmer's living needs as measured by the standard of decent living needs (Pratiwi et al., 2018).

\section{Farmers Household Food Security}

Food security is a very strategic and important matter. Food is a basic need as well as the essence of human life. Therefore, the right to obtain food is a very important part of human rights (Aziz \& Muharni, 2016). Food crop farmers, in this case, farmers who cultivated rice, are an important subject in food availability. Farmers are important actors in food availability, so it is necessary to identify the level of household food security (Purwaningsih et al., 2015). In three districts of Maros Regency, the difference of farmers' household food security of farmers in three locations can be seen using independent sample t-test analysis. The analysis results of household cultivation resilience of rice farming in rainfed rice are displayed in Table 4.

Table 4. Farmers Household Food Security in Maros Regency

\begin{tabular}{|c|c|c|}
\hline District & SFE $<60 \%$ & SFE $\geq 60 \%$ \\
\hline & $\ldots$ pec & ole \\
\hline Lau & $8(26.67 \%)$ & $22(73.33 \%)$ \\
\hline Maros Baru & $5(16.67 \%)$ & $25(83.33 \%)$ \\
\hline Simbang & $13(32.50 \%)$ & $27(67.50 \%)$ \\
\hline Household $\mathrm{F}$ & test: & \\
\hline$t_{\text {count }}$ (contrib & ntributing) & $14.996 * * *$ \\
\hline$t_{\text {count }}$ (Lau wit & & 0.036 \\
\hline $\mathrm{t}_{\text {count }}$ (Lau wit & & 1.423* \\
\hline$t_{\text {count }}$ (Maros & ang) & 1.966* \\
\hline
\end{tabular}

SFE is share of food expenditure: SFE $<60 \%$ food secure, SFE $>60 \%$ food insecure

$* * *, * *$ and $*$ denote significance at p $0.01,0.05$ and 0.10 , respectively

Table 4 shows that in term of household food security based on the share of food expenditure in Lau District, the food secure households were $26.67 \%$ and the food insecure households were $73.33 \%$; in Maros Baru District, $16.67 \%$ were food secure, $83.33 \%$ were food insecure; and in Simbang District, $32.50 \%$ were food secure and $67.50 \%$ were food insecure. These results indicate that rainfed rice farming households display the performance of food insecure farming in all regions. Based on the t-test results, it was significantly different $(p=0.01)$, indicating that farmer households were food insecure in all districts.

Based on the t-test results, the results were significantly different $(p=0.05)$ in Maros Baru and Simbang District. This means that the percentage of the number of farmer households that are food insecure is smaller in Simbang District compared to Maros Baru District. For Lau District and Simbang 
District area, it was significantly different $(p=0.10)$. This means that in Simbang District, the percentage of the number of farmer households that is food insecure is smaller than Lau District. Whereas, Lau and Maros Baru District were not significantly different $(p=0.05$ and 0.10 ). This means that the percentage of farmer households in Lau and Maros Baru Districts that are food insecure is similar.

The composition of household expenditure can be used as a measure to assess the level of economic welfare of the community. The lower the percentage of expenditure on food to total expenditure is, the better the economic level of the community is (Rahmi et al., 2013). The share of food expenditure can be determined by household resilience because the share of food expenditure is inversely related to food security. The higher the share of food expenditure is, the lower the level of household food security is.

\section{Research Implication}

The government always pays great attention to efforts in increasing rice production. The system of providing agricultural facilities and infrastructure continues to be refined so that farmers can be more productive in farming (Jamaluddin, 2016). Increasing production of lowland utilization is very important because rice fields are the main natural resources in rice production (Danuri et al., 2017). The success of increasing rice production in recent years has been led by an increase in productivity, rather than strategy in harvested area. The increase in lowland rice productivity contributed around $56.1 \%$, while the increase in the harvested area accounted for $26.3 \%$ (Jauhari et al., 2020).

Rice productivity in rainfed lowland is generally still low, due to limited water for the needs of rice plant growth which only depends on rainwater. Another problem is the imbalance of nutrient content in the rainfed lowland area. Efforts to improve crop production and maintain productivity can be carried out by meeting the needs of soil nutrients in a balanced manner or with balanced fertilization (Yartiwi et al., 2018). Likewise, farmers in Maros Regency in general made use of balanced fertilizers in managing rice farming in rainfed rice fields. The aim is to increase rice production and maintain nutrient content in rainfed lowland areas.

The contribution of rice farming in rainfed fields to farmers' household income in Maros Regency was still very dominant. This is because most farmers who live in rural areas depend on agriculture for their livelihoods. Agriculture is associated with rural areas and some people work in the agricultural sector, as well as an additional job opportunity (Zuhurony \& Susilowati, 2020). Rice farming greatly contributes to the income of farmer families (Bulanta et al., 2019). The lack of occupational diversification carried out by farmers has created a very large dependence on rice farming. As a result, rice farming income dominates the income in the household. Therefore, an effort is required to find other sources of income to increase farmers' income to support income from rice farming.

The income obtained by farmers in Maros Regency, especially at the research location, was from the results of rice farming in rainfed rice fields, added by income outside rice farming, which had an impact on the household food security of farmers. In general, farmers are more food insecure. This occurs because there is no other income source apart from rice farming, so farmers cannot meet household food needs. Farmers have a strategic position in food security, so they must have the ability to produce food while also having sufficient income to meet family food needs (Soedarto et al., 2020). Food security can be achieved if sufficient food is fulfilled for the community in terms of quality and quantity (Rahmawati et al., 2020). Several aspects that can affect food security are food availability, food security, food access and food quality. These four aspects indicate that food must be available in sufficient quantities and be available at all times in a sustainable manner.

\section{CONCLUSION AND SUGGESTION}

This study shows the production of rainfed lowland rice farming in three districts of Maros Regency, that Maros Baru District had the highest amount of 5,247 $\mathrm{kg}$, followed by Lau District $(4,820 \mathrm{~kg})$ and Simbang District $(4,488 \mathrm{~kg})$. Rainfed rice farming's contribution to farmers' household income in Lau District was $90.0 \%$, Maros Baru District was $70.0 \%$, and Simbang District was $57.5 \%$. Farmer households in those districts had food insecurity with the food expenditure share $73.33 \%, 83.33 \%$, and $67.50 \%$, respectively.

Farmers need to diversify their business apart from rice farming. The effort that must be done is to improve work skills to increase household income. With the increase in income, the food security of farmers' households will increase to become food secure. Increased food security of farmer households 
means that welfare increases, meaning that food is easier and more affordable for the households to obtain.

\section{ACKNOWLEDGMENT}

The author is grateful to the Government of Maros Regency for assisting the availability of information and data related to rainfed rice fields. They meaningfully support both material and non-material assistance in conducting this research.

\section{REFERENCES}

Abdulkadyrova, M. A., Dikinov, A. H., Tajmashanov, H. E., Shidaev, L. A., \& Shidaeva, E. A. (2016). Global food security problems in the modern world economy. International Journal of Environmental \& Science Education, 11(12), 5320-5330. Retrieved from https://files.eric.ed.gov/fulltext/EJ1115556. pdf.

Ahmed, U. I., Ying, L., Bashir, M. K., Abid, M., \& Zulfiqar, F. (2017). Status and determinants of small farming households' food security and role of market access in enhancing food security in rural Pakistan. Research Article, 12(10), 1-15. https://doi.org/10.1371/journal.pone.0185466.

Aminah, S., Sumardjo, Lubis, D., \& Susanto, D. (2015). Strategi peningkatan keberdayaan petani kecil menuju ketahanan pangan. Jurnal Sosiohumaniora, 18(3), 253-261. https://doi.org/10.24198/sosiohumaniora .v17i3.8343.

Anton, G. M., \& Marhawati. (2016). Kontribusi usahatani padi sawah terhadap pendapatan usahatani keluarga di Desa Ogoamas II Kecamatan Sojol Utara Kabupaten Donggala. E-Jurnal Agrotekbis, 4(1), 106-112.

Arida, A., Sofyan, \& Fadhiela, K. (2015). Analisis ketahanan pangan rumah tangga berdasarkan proporsi pengeluaran pangan dan konsumsi energi (Studi kasus pada rumah tangga petani peserta Program Desa Mandiri Pangan di Kecamatan Indrapuri Kabupaten Aceh Besar). Jurnal Agrisep, 16(1), 20-34. Retrieved from http://www.jurnal.unsyiah.ac.id/agrisep/article/vi ew/3028/ 2890.

Arifin, Zulkifli, Biba, M. A., Pata, A. A., \& Sadat, M. A. (2019). Risiko produksi dan efisiensi teknis usahatani padi pada sawah tadah hujan di Kabupaten Maros, Sulawesi Selatan. Jurnal Agrisep, 18(2), 403-411. https://doi.org/10.31186/jagrisep.18.2.403-411.
Arlius, F., Irsyad, F., \& Yanti, D. (2017). Analisis daya dukung lahan untuk sawah tadah hujan di Kabupaten Pasaman Barat. Jurnal Rona Teknik Pertanian, 10(1), 21-33. https://doi.org/10.17969/rtp.v10i1.7246.

Aziz, A., \& Muharni. (2016). Analisis ketahanan pangan rumah tangga pada keluarga pra sejahtera dengan status gizi balita di Kelurahan Sri Meranti Kecamatan Rumbai Kota Pekanbaru. Jurnal Proteksi Kesehatan, 5(1), 60-66. https://doi.org/10.36929/jpk.v5i1.51.

Barokah, U., Rahayu, W., \& Sundari, M. T. (2014). Analisis biaya dan pendapatan usahatani padi di Kabupaten Karanganyar. Jurnal Agric, 26(1 \& 2), 12-19. https://doi.org/10.24246/agric.2014.v26.i1.p1219.

Bulanta, O., Manginsela, E. P., \& Wangke, W. M. (2019). Kontribusi usahatani padi sawah terhadap pendapatan keluarga di Kelurahan Tarata Satu Kecamatan Tomohon Barat Kota Tomohon. Jurnal Agri-Sosio Ekonomi Unsrat, 15(2), 235-242. https://doi.org/10.35791/agrsosek.15.2.2019.242 48.

Danuri, Radian, \& Nurjani. (2017). Pengaruh jarak tanam dan jumlah bibit terhadap pertumbuhan dan hasil padi di lahan sawah tadah hujan. Agrovigor: Jurnal Agroekoteknologi, 10(2), 121127. https://doi.org/ 10.21107/agrovigor.v10i2.3056.

Emtamoile, R. N., Sahusilawane, A. M., \& Kaplale, R. (2016). Aksesibilitas pangan rumah tangga di Desa Manuweri, Kecamatan Babar, Timur Kabupaten Maluku Barat Daya. Jurnal Agrilan, 4(3), 71-83.

Feryanto. (2017). Pembiayaan pertanian dan upaya meningkatkan kesejahteran petani: Analisa data makro. AGRICORE: Jurnal Agribsnis Dan Sosial Ekonomi Pertanian, 2(2), 291-357. Retrieved from Retrieved from http://jurnal.unpad.ac.id/agricore/ article/view/15145/pdf.

Jamaluddin. (2016). Analisis tingkat efesiensi pengunaan faktor produksi usahatani padi varietas unggul nasional, unggul lokal dan hibrida pada sawah tadah hujan di Kecamatan Bangkinang Kabupaten Kampar. Jurnal Agribisnis, 18(2), 118131. https://doi.org/10.31849/agr.v18i2. 773.

Jauhari, S., Winarni, E., \& Sahara, D. (2020). Keragaan pertumbuhan dan produktivitas padi gogo Varietas Unggul Baru (VUB) di lahan sawah tadah hujan di Kabupaten Semarang, Jawa Tengah. Pangan, 29(1), 25-34. https://doi.org/10.33964jp.v29i1.454. 
Lailiyah, N., Timisela, N. R., \& Kaplale, R. (2017) Analisis produksi padi sawah (Oryza Sativa L) tadah hujan di Desa Lea Wai Kecamatan Seram Utara Timur Kobi. Agrilan: Jurnal Agribisnis Kepulauan, 5(2), 151-165. Retrieved from https://ojs.unpatti.ac.id/ index.php/agrilan/article/view/179/287.

Matus, S. S., Paloma, S. G. Y., \& Mary, S. (2012). Economics of food security: Selected issues. BioBased and Applied Economics, 1(1), 65-80. https://doi.org/10.13128/BAE-10552.

Norfahmi, F., Kusnadi, N., Nurmalina, R., \& Winandi, R. (2017). Analisis curahan kerja rumah tangga petani pada usahatani padi dan dampaknya terhadap pendapatan keluarga. Jurnal Informatika Pertanian, 26(1), 13-22. Retrieved from http://ejurnal.litbang.pertanian.go.id/index.php/I P/ article/view/5804/6638.

Nurasa, T. (2013). Meningkatkan pendapatan petani melalui difersivikasi tanaman hortikultura di lahan sawah irigasi. SEPA: Jurnal Sosial Ekonomi Pertanian Dan Agribisnis, 10(1), 71-87. https://doi.org/10.20961/ sepa.v10i1.14110.

Nurdin. (2010). Perkembangan, Klasifikasi dan Potensi Tanah Sawah Tadah Hujan dari Bahan Lakustrin di Paguyaman, Gorontalo. In Tesis. Bogor (ID): Sekolah Pascasarjana. Institut Pertanian Bogor.

Piran, R. D., Pudjiastuti, A. Q., \& Dyanasari. (2018). Dinamika generasi muda pertanian dalam pemilihan usahatani tanaman pangan. Jurnal Agriekonomika, 7(2), 149-157. http://doi.org/10.21107/agriekonomika.v7i2 .4133 .

Pothukuchi, K. (2004). Community Food Assessment: A first step in planning for community food security. Journal of Planning Education and Research, 23(4), 356-377. https://doi.org/10.1177/0739456X0426 4908.

Prasetyaningtyas, D., \& Nindya, T. S. (2017). Hubungan antara ketersediaan pangan dengan keragaman pangan rumah tangga buruh tani. Media Gizi Indonesia, 12(2), 149-155. http://doi.org/10.20473/mgi.v12i2.149-155.

Pratiwi, C. A., Gunawan, D. S., \& Istiqomah. (2018). Analisis ekonomi usahatani padi dan kelayakan rumah tangga tani di Desa Sambeng Kulon Kecamatan Kembaran Kabupaten Banyumas. JSEP, 11(1), 33-45. Retrieved from https://jurnal.unej.ac.id/ index.php/JSEP/article/view/5315/5525.

Purwaningsih, Y., Hartono, S., Masyhuri, \& Mulyo, J. H. (2010). Pola pengeluaran pangan rumah tangga menurut tingkat ketahanan pangan di Provinsi Jawa Tengah. Jurnal Ekonomi Pembangunan, 11(2), 236-253.

Purwaningsih, Y., Sutomo, \& Istiqomah, N. (2015). Analisis dampak alih fungsi lahan terhadap tingkat ketahanan pangan rumah tangga petani di Karanganyar, Jawa Tengah. Jurnal Agraris, 1(2), 98-107. https://doi.org/ 10.18196/agr.1213.

Raes, D., Kafiriti, E. M., Wellens, J., Deckers, J., Maertens, A., Mugogo, S., Dondeyne, S., \& Descheemaeker, K. (2007). Can soil bunds increase the production of rain-fed lowland rice in South Eastern Tanzania. Agricultural Water Management, 89, 229-235. https://doi.org/10.1016/j. agwat.2007.01.005.

Rahmawati, M., Noor, T. I., \& Yusuf, M. N. (2020). Analisis ketahanan pangan rumah tangga petani padi di Desa Pawindan Kecamatan Ciamis Kabupaten Ciamis. Jurnal Ilmiah Mahasiswa Agroinfo Galuh, 7(3), 777-788. https://doi.org/10.25157/jimag.v7i3.4016.

Rahmi, R. D., Suratyah, K., \& Mulyo, J. H. (2013). Ketahanan pangan rumah tangga petani di Kecamatan Ponjong Kabupaten Gunung Kidul. Jurnal Agro Ekonomi, 24(2), 190-201.

Razak, M. I. M., Hamzah, A. S. M. A., Abas, N., Idris, R., \& Ibrahim, Z. (2013). Sustaining food production for food security in Malaysia. Journal of Economics and Development Studies, 1(2), 19-25. Retrieved from http://jedsnet.com/vol-1-no-2september-2013-jeds.

René, K. K., Koné, B., Firmin, K. K., Florant, Z., Joachim, T. M., Albert, Y. K., Emanuel, D. A., \& Daouda, K. (2016). Variations of rainfall and air temperature affecting rainfed rice growth and yield in a Guinea savanna zone. Journal of Agriculture and Environmental Sciences, 5(1), 65-77. https://doi.org/10.15640/jaes.v5n1a7.

Roy, R., \& Chan, N. W. (2015). Determinants of sustainable irrigated and rainfed rice farming in Bangladesh. Journal of Agricultural Science and Technology, 17(6), 1421-1435. Retrieved from https://www.researchgate.net/publication/ 284898000_Determinants_of_Sustainable_Irrigat ed_and_Rainfed_Rice_Farming_in_Bangladesh.

Sari, P. N., Hilmi, Y. S., \& Hariswanti, W. S. (2018). Kelayakan dan nilai tukar petani padi organik di Kabupaten Sleman. Jurnal Agriekonomika, 7(2), 120-128. http://doi.org/10.21107/agriekonomika.v7i2.3928 
Setiawati, Herdian, D., \& Santi, M. (2016). Kontribusi pendapatan usahatani padi lebak terhadap total pendapatan keluarga kasus di Desa Arisan Musi Timur Kecamatan Muara Belida Kabupaten Muara Enim. Jurnal TriAgro, 1(2), 33-45. Retrieved from http://univ-tridinanti.ac.id/ejournal/index.php/ pertanian/article/view/416.

Sianipar, J. E., Hartono, S., \& Hutapea, R. T. P. (2012). Analisis ketahanan pangan rumah tangga tani $\mathrm{d}$ Kabupaten Manokwari. SEPA: Jurnal Sosial Ekonomi Pertanian Dan Agribisnis, 8(2), 68-74.

Siregar, A. Z., \& Yurnaliza. (2017). Potential, Opportunities and Strategies (POS) of rice productivity through integrated pest management in tidal land paddy Percut, Sumatera Utara, Indonesia. International Journal of Advances in Science Engineering and Technology, 5(2), 4-9. Retrieved from http://www.iraj.in/ journal/journal_file/journal_pdf/6-43215184190314-9.pdf.

Soedarto, T., Hendrarini, H., Alit, R., \& Anggriawan, T. P. (2020). Penerapan dan evaluasi pengembangan perilaku petani dalam mewujudkan ketahanan pangan rumah tangga berbasis teknologi informasi di Kabupaten Bangkalan Madura. SCAN, XV(3), 38-42. Retrieved from http://www.riset.unisma.ac. idindex.phpju-kearticle-vi.

Syamsiyah, N., Thoriq, A., Pardian, P., Karyani, T., \& Kusno, K. (2017). Tingkat pendapatan usahatani padi dan kontribusinya terhadap pendapatan petani. Jurnal Agribisnis Terpadu, 10(1), 76-88. http://doi.org/10.33512/ jat.v10i1.5057.

Tambi, M. D. (2019). Agricultural training and its impact on food crop production in Cameroon.
Journal of Socioeconomics and Development, 2(1), 1-11. https://doi.org/10.31328/jsed.v2i1.740.

Tashikalma, A. K., Sani, R. M., \& Giroh, D. Y. (2014). Comparative profitability analysis of selected rainfed and irrigated food crops in Adamawa State, Nigeria. Global Journal of Pure and Applied Sciences, 20, 77-87. http://dx.doi.org/10.4314/gjpas.v20i2.1.

Wardie, J., Masliani, \& Sintha, T. Y. E. (2019). The study of household food security levels in Palangka Raya City. Journal of Socioeconomics and Development, 2(1), 32-37. https://doi.org/10.31328/jsed.v2i1.952.

Wardie, J., \& Sintha, T. Y. E. (2018). The Sustainability level of the rice farming in the peatland at the Kapuas Regency, Central Kalimantan. Journal of Socioeconomics and Development, 1(1), 38-42. https://doi.org/ 10.31328/jsed.v1i1.531.

Yartiwi, Romeida, A., \& Utama, S. P. (2018). Uji adaptasi varietas unggul baru padi sawah untuk optimasi lahan tadah hujan berwawasan lingkungan di Kabupaten Seluma Provinsi Bengkulu. NATURALIS: Jurnal Penelitian Pengelolaan Sumberdaya Alam Dan Lingkungan, 7(2), 91-97. https://doi.org/10.31186/naturalis.7.2.6027.

Zuhurony, H., \& Susilowati, D. (2020). Analisis kontribusi usahatani padi terhadap pendapatan rumah tangga petani padi di Lingkungan Sekarputih Kota Mojokerto Jawa Timur. JU-Ke (Jurnal Ketahanan Pangan), 4(1), 17-27. Retrieved from http://www.riset.unisma.ac.idindex.phpju-kearticle-vi. 